TIDD PFBC DEMONSTRATION PROJECT TECHNICAL PROGRESS REPORT

THIRD QUARTER, CY 1992
$\mathrm{DOE} / \mathrm{MC} / 24132--3311$

DE93 010347

\author{
DISCLAIMER
}

This report was prepared as an account of work sponsored by an agency of the United Stater Government. Neither the Ohio Power Company, the American Electric Power Service Corporation, or the United states Government nor any agency thereof, nor any of their employees, nor any of their contractors, subcontractors, or their employees makes any warranty, express or implied, or assumes any legal liability or responsibility for the accuracy, completeness, or usefulness of any information, apparatus, product, or process disclosed, or represents that its use would not infringe privately owned rights. Reference herein to any specific commercial product, process or service by tradename, trademark, manufacturer, or otherwise, does not necessarily constitute or imply its endorsement, recommendation, or favoring by the Ohio Power Company, the American Electric Power Service Corporation, and the United states Government or any agency thereof. The views and opinions of authors expressed herein do not necessarily state or reflect those of the Ohio Power Company, the American Electric Power Service Corporation, and the United States Government or any agency thereof.

\author{
Prepared by: \\ American Electric Power Service Corporation \\ Columbus, Ohio 43215
}

Prepared for:

The United States Department of Energy

Under DOE Instrument NO. DE-FC21-87 MC-24132.000

October, 1992 
GLOSSARY OF ACRONYMS AND ABBREVIATIONS USED IN THIS REPORT ii

I. INTRODUCTION AND SUMMARY 1

II. DESIGN AND PERMITTING 3

A. Mechanical Engineering Division 3

1) Engineering and Design 3

2) Meetings $\quad 6$

3) Phase III - Testing and Data Collection 6

B. Instrumentation and Controls Division 11

1) Balance of Plant Design Major Systems Worked 11

$\begin{array}{ll}\text { 2) Meetings } & 12\end{array}$

C. Environmental and Technical Assessment Division 12

D. Electrical Engineering Department 13

1) Vendor Meetings/Plant Trips 13

2) Other Engineering Activities 13

III. PROJECT MANAGEMENT AND CONSTRUCTION 15

1) Major Construction Activities 15

IV. TIDD PFBC PLANT OPERATIONS 16

A. Operations $\quad 16$

B. Maintenance $\quad 32$

$\begin{array}{ll}\text { C. Performance } & 35\end{array}$

V. MANPOWER REPORT $\quad 36$

VI. COST DATA 38 


\section{GLOSSARY OF ACRONYMS AND ABBREVIATIONS USED IN THIS REPORT}

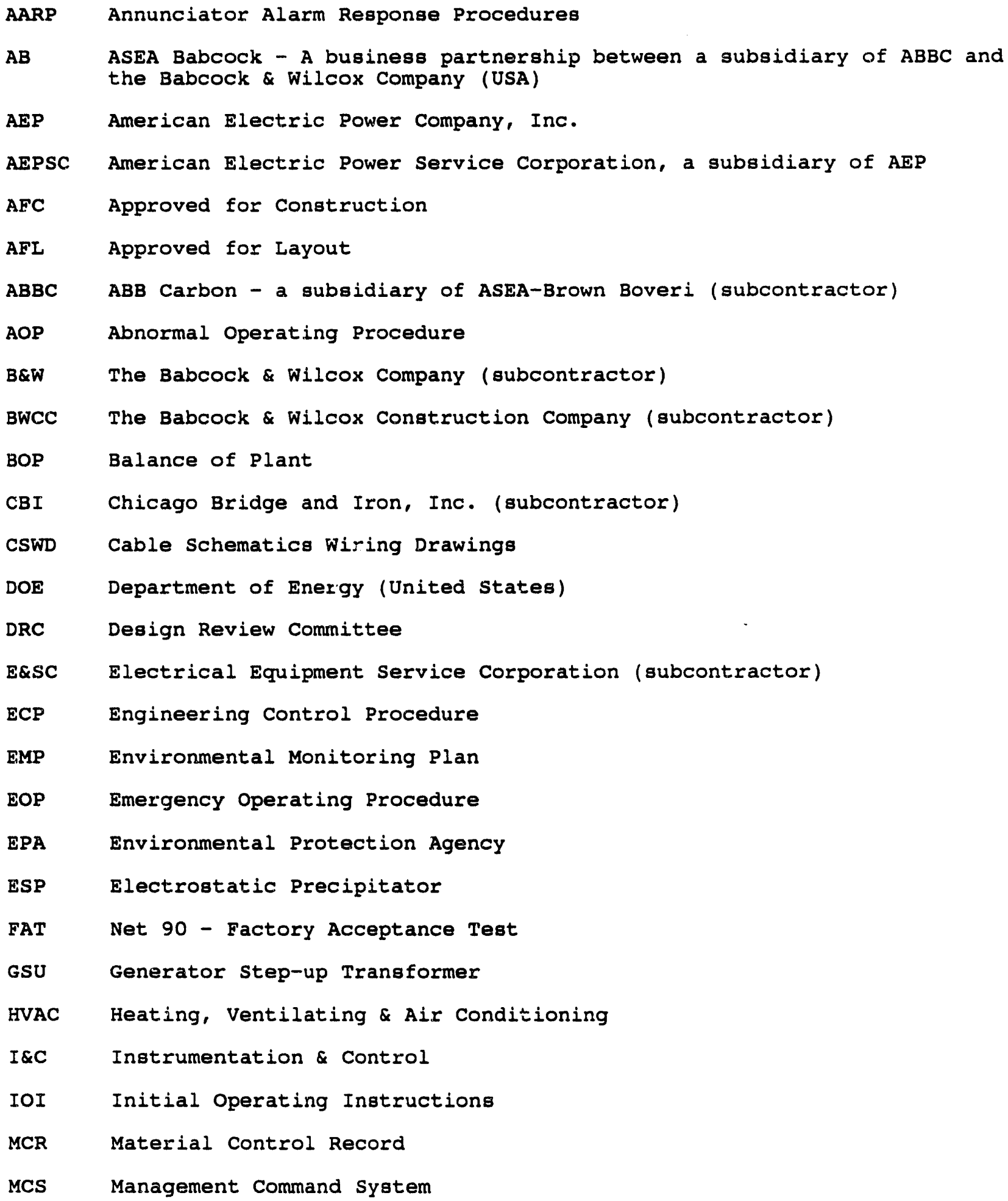




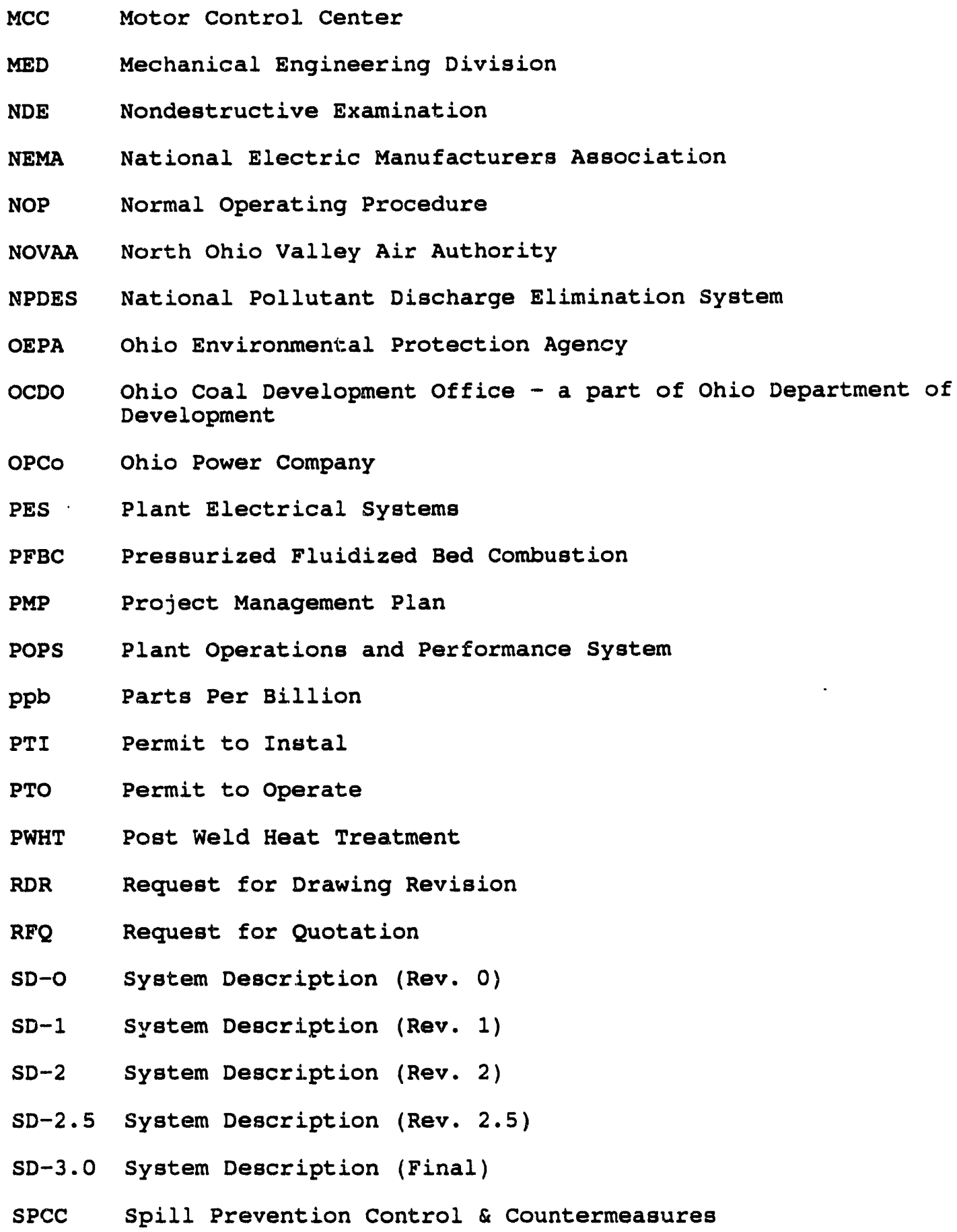




\section{INTRODUCTION AND SUMMARY}

This is the 22nd Technical Progress Report submitted to the Department of Energy in connection with the Cooperative Agreement between the DOE and the Ohio Power Company for the Tidd PFBC Demonstration Plant. This report covers the period from July 1, 1992 to september 30, 1992.

Major activities during this period involve:

- The unit was operated for a total of 903 hours (including gas turbine air prewarming). There were 9 gas turbine starts, 11 preheating starts, and 8 operating periods with coal fire. The peak gross output of 59 MWH was achieved for the period of 1600 to 1700 hours on september 23, 1992. The longest coal fire was 422 hours beginning at 1349 hours on August 9, 1992.

- During the quarter, total gross generation was 32,418 MWH, and coal consumption was 15,846 tons.

- Testing was completed on the gas turbine blade resonance frequency problem. The report showed that a resonant frequency problem existing at high IPT speeds and at a mostly closed guide vane position. An operating curve was developed by $A B B C$ to avoid the points of blade resonance.

- Monitoring of solid, liquid and gaseous waste streams, as detailed in the operations phase monitoring requirements in the EMP, were performed throughout the quarter. Regults of the monitoring will be included in the Third Quarter - 1992 EMP Report, which is scheduled to be sent to the DOE by November 30,1992 . 
Major items planned for the next period include:

- Continuation with the operation and testing of the unit. Attempts will be made to improve sulfur retention and sorbent utilization (on a mass basis) by improving pneumatically-fed sorbent distribution and testing with different types of sorbents (dolomite vs limestone). 
A. Mechanical Engineering Division

\section{Engineering and Design}

The Mechanical Engineering Division has been involved in the following engineering and design activities duxing this reporting period:

- Secondary Ash Removal System:

During the reporting period, problems continued to impact the secondary ash removal system. The first problem related to the inability of the secondary cyclone 524 ash line to transport ash during most of the runs this quarter. The other problem concerned the erosion of the secondary ash removal lines in the internal secondary ash coolers.

- S24 Ash Line Problem:

During the spring gas turbine/HGCU outage, the 524 ash line was rerouted from the north internal ash collection header over to the south ash collection header. This rerouting was required to balance out the two headers after the 521 cyclone was eliminated for the HGCU filter tests. The elimination of 521 left only two ash lines going into the south header, while the north header had four ash lines going into it. When 524 was transferred to the south header, 
then both the headers became balanced with each having three lines.

During the 30-day run in June and early July, 524 remained out of service and plugged for 30 days. An inspection of the ash line during the subsequent outage revealed a piece of hard refractory lodged in the suction nozzle of the ash line, thus significantly reducing the ash line capacity.

During this outage, the $\$ 24$ dip leg assembly was removed and old 521 dip leg assembly was installed on 524. This replacement made all the secondary dip legs to be identical.

During the next run series, the 524 ash line again remained plugged throughout the run. Air flow tests conducted on the ash line during the subsequent outage indicated no pluggage or restrictions in the ash line between the dip leg suction nozzle and the south collection header. In addition, a blowdown line was installed from the suction nozzle to outside the combuator vessel for testing the 524 ash line.

During the next run, 524 again showed signs of pluggage. The blowdown line was used and verified the ability to get ash into the suction nozzle from the dip leg. 
On the next outage, the entire 524 ash line was dismantled and inspected. A borescopic inspection showed no problems in the ash line up to the collection header. Inside the collection header, between 524 and the next ash line entrance, a hard deposit was found which restricted $80 \%$ of the flow path. From previous inspections it was known that this deposit had not been there during the two previous runs. On the next run, the 524 ash line operated properly.

\section{Agh Line Erosion:}

During the bed surface outage in the Fall of 1991, the flanged cast secondary tee bends were replaced by welded fittings in order to eliminate air in-leakage. After approximately 1,400 hours of operation, erosion wore through a return chamber in the 523 ash cooler package. Subsequent inspections revealed erosion on several return chambers. Therefore, it was decided to install new return chambers on all the coolers during the forthcoming October, 1992 outage.

Gas Turbine:

Testing was completed on the gas turbine blade resonance frequency problem. The report showed that a resonant frequency problem existed at high LPT speeds and at a mostly closed guide vane position. An operating curve was developed by $A B B C$ to avoid the points of blade resonance.

Tidd PFBC Demonstration Project DOE Instrument DE-FC21-87 MC24132.000
Technical Progress Report

5 Third Quarter CY 1992 


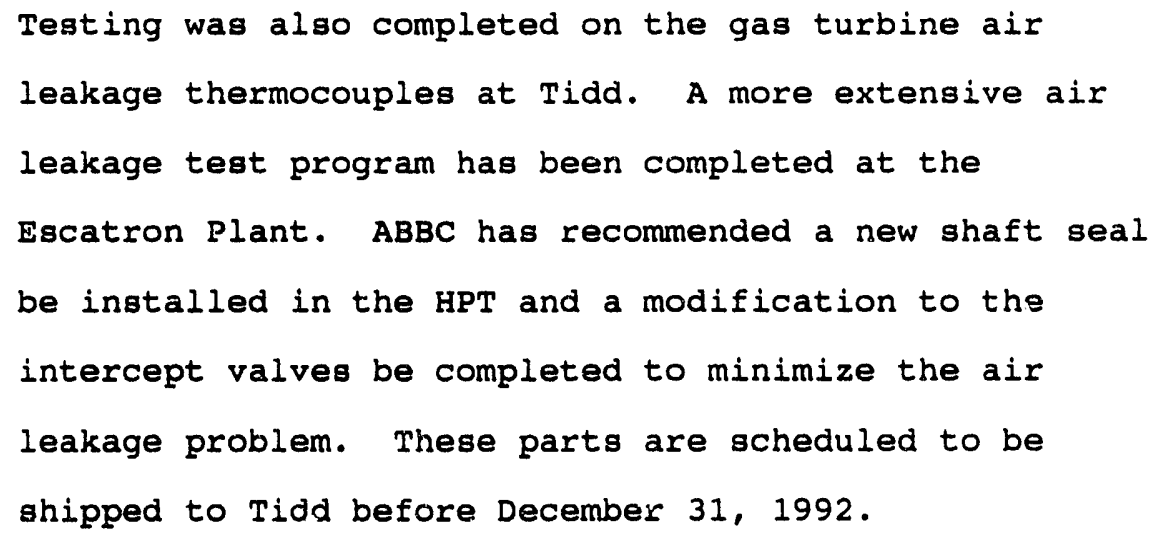

\title{
2. Meetings
}

The Tidd Test Committee met on the following dates:

July $23 \& 24,1992$

August 6,1992

August 27,1992

\section{Phase III - Testing and Data Collection}

\begin{abstract}
As part of the commercial plant program to improve sulfur capture and sorbent utilization, a series of tests were run during the period of August $9-27$ to help evaluate the feasibility of injecting all, or part, of the sorbent with the coal-water paste. This testing was considered a prexequisite to instaliing a permanent system to feed sorbent with the coal, the cost of which will be separately funded under AEP's PFBC-001 project.
\end{abstract}


Factors evaluated during the tests included:

- Impact on sorbent utilization.

- Effects on paste preparation system mixing.

- Effects on coal injection system function, especially pumpability of paste.

- Potential for formation of in-bed sorbent deposits.

A temporary variable speed screw feeder was installed to transport -4 mesh sorbent material from the bottom of the 200 ton sorbent storage hopper to the chute between the coal weigh feeder and the coal mixer. A second temporary variable speed screw feeder was installed to transport -200 mesh sorbent material from the 8 ton fines bin to the chute between the coal weigh feeder and the coal mixer.

Although no direct means were provided to weigh the material in either case, provisions were made to periodically divert the flow stream into 55-gallon drums for sampling and weighing. The material flow rate determined by periodic timed weighing proved to be relatively consistent at a given feeder speed, which allowed approximate measurements of either -4 mesh or -200 mesh material flow to be made.

Four tests were performed. The first was a baseline test with the normal pneumatic feed of the typically prepared -4 mesh sorbent. The second was with approximately 608 of the -4 mesh sorbent mixed with the coal paste, with the remainder fed in pneumatically. The third was with all of the -4 mesh sorbent fed with the coal paste. The fourth was with approximately 408 of the sorbent being fed as -200 mesh 
fines with the coal paste, and the remainder being -4 mesh prepared sorbent fed pneumatically.

Operating conditions for a.ll tests were approximately as follows:

$\begin{array}{ll}\text { Bed Level: } & 116 \text { inches } \\ \text { Bed Temperature: } & 1550^{\circ} \mathrm{F} \\ \text { Sulfur Retention: } & 908 \\ \text { Excess Air: } & 3.5 \% \text { average }\end{array}$

Baseline test sorbent requirements were significantly higher than were expected given the Tune, 1992 acceptance test results.

Test results are summarized below:

Sorbent Utilization

\section{Sorbent Tests}

\begin{tabular}{|c|c|c|c|c|}
\hline & $\underline{08 / 11 / 92}$ & $\underline{08 / 18 / 92}$ & $\underline{08 / 20 / 92}$ & $\underline{08 / 25 / 92}$ \\
\hline & Test 1 & Test 2 & Test 3 & Test 4 \\
\hline Sulfur Retention, Percent & 89.7 & 89.7 & 91.1 & 89.2 \\
\hline Test $\mathrm{Ca} / \mathrm{s}$ & 2.5 & 3.0 & 3.0 & 2.5 \\
\hline $\begin{array}{l}\mathrm{Ca} / \mathrm{s} \text { for } 908 \text { Retention } \\
\text { (Predicted) }\end{array}$ & 2.6 & 3.1 & 2.9 & 2.5 \\
\hline $\begin{array}{l}\mathrm{Ca} / \mathrm{S} \text { for } 958 \text { Retention } \\
\text { (Predicted) }\end{array}$ & 3.4 & 4.0 & 3.7 & 3.3 \\
\hline Mean Bed Temperature, ${ }^{\circ} \mathrm{F}$ & 1544 & 1547 & 1548 & 1552 \\
\hline $\begin{array}{l}\text { Sulfur Retention at Test } \\
\mathrm{Ca} / \mathrm{S} \text { and } 1580^{\circ} \mathrm{F} \text { Bed } \\
\text { Temp., (Predicted) }\end{array}$ & 91.0 & 90.9 & 92.1 & 90.2 \\
\hline
\end{tabular}




\section{Sorbent Tests}

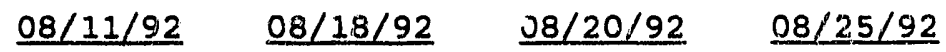

Test 1 Test 2 Test 3 Tegt 4

$\mathrm{Ca} / \mathrm{S}$ for 908 Retention at $1580^{\circ} \mathrm{F}$ Bed Temp. (Predicted)

$\mathrm{Ca} / \mathrm{S}$ for $95 \%$ Retention at $1580^{\circ} \mathrm{F}$ Bed Tem. (Predicted)
2.4

2.9

$2 \cdot 7$

2.4
3.8

3.6

3.2

Tests ? and 3, with -4 mesh prepared sorbent in the coal

paste, both required higher $\mathrm{Ca} / \mathrm{s}$ molar ratios than the baseline test to attain 908 sulfur retention 13.1 and 2.9 versus 2.6 for the baseline test). Pumpability of the coal paste was acceptable. The total water content required as a percentage with total solids (coal and sorbent) was less with the -4 mesh sorbent in the paste than with coal alone.

Test 4, with fine dolomite in the coal paste, required a slightly lower $\mathrm{Ca} / \mathrm{s}$ molar ratio than the baseline test to attain 908 sulfur retention $(2.5$ versus 2.6 for the baseline test). Pumpability of the coal paste was acceptable and paste quality was noted as improved. The total water content required as a percentage with total solids was more with dolomite fines in the paste than with the coal alone.

No in-bed deposit formations were observed during the test series. 
Attempts were made at testing a dolomite/limestone (5.78 Mgo, 47.48 CaO) which was received from National Limes, Delaware, Ohio, quarry as the sorbent. The unit was started up on september 22 with Plum Run dolomite. The feed of limestone began late on september 23 , after all of the dolomite was purged from the system. On september 24, uneven bed temperature conditions resulted in an automatic combustor trip. A significant quantity of egg-shaped sinters were found to be the cause. The unit was restarted on September 28 with limestone.

The coal paste splitting air flow was increased significantly in an attempt to avoid sintering. However, bed conditions similar to the previous run began to appear during the evening of september 30 . The unit was manually tripped in the early morning of October 1. The sinters were again found to be present.

Laboratory tests were performed to determine whether the limestone had a fluxing effect on the coal ash. While the limestonc did lower the coal ash fusion initial deformation • temperature somewhat as compared to the dolomite, the magnitude of change was not considered significant.

While there is significant circumstantial evidence that the limestone is the cause of this sintering, it is felt that other factors, such as coal paste consigtency or poor fuel splitting, cannot be ruled out. We are continuing to investigate this matter.

Tidd PFBC Demonstration Project DOE Instrument DE-FC21-87 MC24132.000
Technical Progress Report

10 Third Quarter CY 1992




\section{B. Instrumentation and Controls Division}

1. Balance of Plant Design Major Systems Worked on or Completed

- The $\mathrm{O}_{2}$ analyzer system operation was improved by the new heat tracing, which was added at the end of last. quarter. However, pluggage problems still persist at the inlet to the sample line. This problem will be addressed next quarter.

- Sorbent fines is a project to add the sorbent to the coal paste in hopes of achieving better sulfur capture. I\&C assisted the Material Handling Section in the development of an $\mathrm{RDR}$, drawing reviews, and control development. I\&C also produced the Instrumentation and Controls Engineering Package and a first cut at the control philosophy.

- The Plant Monitoring Section, with the Performance Section, tested the remote data capture program recently installed at Tidd. This program permits historical data to be transferred into spreadsheets (Lotus or Enable).

- The setup of trend displays in pops has been enhanced to allow operators and other users more flexibility in customizing trends on line.

Tidd PFBC Demonstration Project DOE Instrument DE-FC21-87 MC24132.000
Technical Progress Report 11 Third Quarter CY 1992 


\section{Meetings}

- I\&C attended a meeting concerning the sorbent fines system with the contractor (Smoot) and other AEPSC personnel on July 21, 1992. At this meeting, Material Handling indicated a scope change involving segregation of the sorbent fines at the plant instead of receiving shipment of sorbent fines directly.

- On August 4, 1992, I\&C attended a meeting with MED, CED, Degign and Project Management concerning project schedules, missing design information, and project scope. Initial submittal of vendor drawings was scheduled for August 12, 1992, and Rev. O ICE Package was scheduled for August 27, 1992.

C. Environmental and Technical Assessment Division

- All air-related monthly and quarterly reports were filed with the North Ohio Valley Air Authority and Ohio EPA, as required.

- Ohio Air PTO \#174105003B005 for the auxiliary boiler was renewed July $21,1992$.

- Ohio Air PTO \#174105003B004 for the main combustor was received July 16, 1992. PTO \#174105003B006 for the portable diesel generator was also received in July. 
- The DOE's Environmental Monitoring Plan requires quarterly reports be filed within 60 days of the quarter's end. In compliance with that requirement, the EMP Quarterly Report for the second Quarter (April - June), 1992 was submitted to the DOE in late August.

- Monitoring of solid, liquid and gaseous waste streams, as detailed in the operations phase monitoring requirements in the EMP, were performed throughout the quarter. Results of the monitoring will be included in the Third Quarter - 1992 EMP Report due to the DOE at the end of November.

\section{Electrical Inqineering Department}

1. Vendor Meetings/Plant Trips

On July 17, 1992, a PES engineer visited Tidd PFBC Plant to test critical power invertor "C" during black plant switching conditions. The tests indicated that an adjustment of the invertor's transfer board would result in a more secure critical power bus. All three critical power invertors were adjusted.

\section{Other Engineering Activities}

- Purchased replacement current transformers (CT's) for the failed steam turbine neutral CT's. Issued P.O. \#04924-071-2X on July 6, 1992. Equipment delj.vered October 1, 1992 .

Tidd PFBC Demonstration Project DOE Instrument DE-FC21-87 MC24132.000
Technical progress Report

13 Third Quarter CY 1992 
- Initiated RDR \#TI-00-7212 for revision of the black plant trip and diesel start scheme september 9, 1992. Approved September 14, 1992, and design drawings issued to the plant on september $30,1992$.

- Currently working on RDR \#TI-00-7045, Sorbent Fines syatem. 


\section{PROJECT MANAGEMENT AND CONSTRUCTION}

No major construction activities pertinent to this plant were performed during the period from July 1 through september 30 . 
IV. TIDD PFBC PLANT OPERATIONS

A. Operations

The following is a summary of accumulated operating data for the period July 1, 1992 through september 30, 1992:

$\begin{array}{lr}\text { Steam Turbine Generation } & 27,025 \mathrm{MWH} \\ \text { Gas Turbine Generation } & 5,393 \mathrm{MWH} \\ \text { Total Gross Generation } & 32,418 \mathrm{MWH} \\ \text { Peak Generation for 1 Hour } & 59 \mathrm{MWH} \\ & 86 \text { Hours } \\ \text { Total Oil Fire Operating Time } & 726 \text { Hours } \\ \text { Total Coal Fire Operating Time } & 15,846 \text { Tons } \\ & 13,061 \text { KLB } \\ \text { Total Coal Injected } & \\ \text { Total sorbent Injected } & \end{array}$

The unit was operated for a total of 903 hours (including gas turbine air prewarming). There were 9 gas turbine starts, 11 bed preheating starts, and 8 operating periods with coal fire. The peak gross output of 59 MWH was for the period of 1600 to 1700 hours or september 23, 1992. The longegt coal fire was 422 hours beginning at 1349 hours on August 9, 1992.

The unit was in service at the beginning of the quarter. The start-up was June 8, 1992, and the unit was removed from service July 10, 1992 for inspection following the 30-day acceptance run.

Tidd PFBC Demonstration Project DOE Instrument DE-FC21-87 MC24132.000
Technical Progress Report 16 Third Quarter CY 1992 


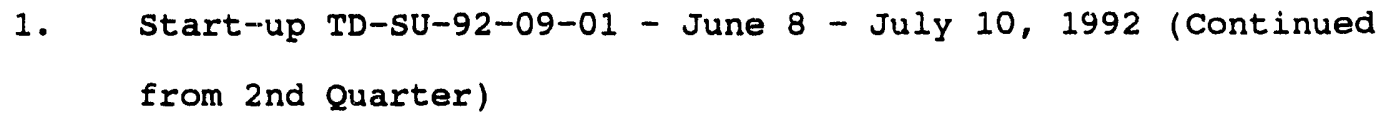

A test was also conducted to determine if the secondary ash could be removed by a baghouse. (Duct opacity did not drop during this test.)

The bed level was lowered to approximately 95", and at 1400 hours on July 10, 1992, the combustor was tripped. A steam turbine trip followed at 1403 hours.

After the trip, the paste nozzles were reversed while the bed level was still above the nozzles, using LP nitrogen for the splitting air supply. This appeared to have worked very well.

The gas turbine was tripped at 2025 hours on July 10, 1992 . Air cooling and feedwater circulation was continued in preparation for maintenance outage activities.

Full load acceptance testing, a 30-day reliability run, and 740 hours of continuous coal fire were accomplished during the run.

Tidd PFBC Demonstration Project DOE Instrument DE-FC21-87 MC24132.000
Technical Progress Report

17 Third Quarter CY 1992


2. Start-up TD-SU-92-10-01 - July $26-27,1992$

The combustor was released by Maintenance at 1500 hours on July 25, 1992. Gas recirculation warming began at 1235 hours on July 26, 1992.

The gas turbine was rolled at 2111 hours and paralleled at 2127 hours on July 26, 1992. Intercept and bypass valves were opened at 2137 hours.

Problems were experienced while attempting to light the bed preheater. After the initial light-off, when the temperature control valve was released to go to minimum fire position, the flame became unstable and the preheater tripped on $108 s$ of flame. After trying several solutions for correcting the problem, the bed preheater was successfully lit at 0405 hours on July 27, 1992, by not allowing the control valve to go to minimum fire position.

The \#24 cyclone showed signs of being plugged as soon as temperatures in the boiler began increasing. (Number 24 cyclone remained plugged for the entire run.)

At 0903 hours, the steam turbine was rolled and paralleled.

The duct opacity was high the entire time while bringing the bed to start level. Fine bed ash material carryover limited the rate of bed level increase that was possible because of primary cyclone ash flow and pressure limitations. While increasing the bed level with 274 system, the south

Tidd PFBC Demonstration Project

DOE Instrument DE-FC21-87 MC24132.000
Technical Progress Report

18 Third Quarter
CY 1992 
reinjection vessel outlet " $L$ " valve plugged. All attempts at unplugging it failed.

At 1247 hours on July 27, 1992, coal fire was initiated with a bed level of $24 "$.

As bed temperature increased to the point where the controls for fuel master and bed temperature are pulsed to auto, the temperatures began to decrease. (It was determined later that the bed temperature station had been mistakenly left in manual with a zero output.) Bed temperatures were not able to be brought back up quickly enough and at 1300 hours, the combustor was manually tripped. The steam turbine tripped at 1302 hours. The unit was secured following the trip. Because of the plugged reinjection vessel, there was not enough bed material available for another start-up. It was then decided to cool and open the combustor to unplug the south bed ash reinjection vessel as well as \#24 secondary cyclone.

3. Start-up TD-SU-92-11-01 - August $1-2,1992$

The combustor was released by Maintenance at 1025 hours on August 1, 1992. Gas recirculation warming was started at 1940 hours.

The gas turbine was rolled and paralleled at 0219 hours on August 2, 1992, with the valves being opened at 0224 hours. 
The bed preheater again had flame-out when the temperature control valve was ordered to the minimum fire position. The minimum fire position was increased and the preheater fire established at 0852 hours.

Again, \#24 cyclone showed no signs of any ash flow.

The steam turbine was rolled and paralleled at 1353 hours on August 2 .

Duct opacity was high throughout bed level increase, as was ash loading in the primary cyclone ash system.

A coal fire was initiated at 1954 hours, but was ordered off because \#4 coal nozzle was plugged. Attempts to clean it were unsuccessful and at 2245 hours, the combustor was tripped. At 2335 hours, the gas turbine was tripped. The Maintenance Department was issued a clearance to allow mechanical removal and cleaning of \#4 coal nozzle. (The \#1 coal nozzle was also removed and cleaned.)

4. Start-up TD-SU-92-11-02 - Augugt 3-4, 1992

The mechanical cleaning of the paste nozzles was completed by the Maintenance Department and the gas turbine was rolled and paralleled at 0511 hours on August 3, 1992. combustor air flow was establighed at 0518 hours; oil fire was initiated at 0558 hours.

The \#24 cyclone was sti.11 plugged.

Tidd PFBC Demonstration Project

DOE Instrument DE-FC21-87 MC24132.000
Technical Progress Report 20 Third Quarter CY 1992 
The steam turbine was rolled and paralleled at 0911 hours.

The duct opacity again was high while establighing start bed level, and also the primary ash loading in the transport piping. This limited the rate of bed level increase.

A coal fire was initiated at 1231 hours, but was ordered off when the \#4 coal paste pump did not pump through the nozzle. Attempts at clearing it were unsuccessful. A successful coal fire with five pumps was established at 1617 hours on August 3, 1992 .

After increasing air flow and pressure vessel pressure, the \#24 cyclone was pulsed and showed signs of at least some ash flow. (Later it plugged again.)

Sorbent injection was initiated with the east line at 1850 houra.

Bed level was increased to approximately 40 inches and bed material inventory was built to enable increase to oncethrough operation. Throughout this period, adjustments were made to the precipitator TRs to optimize the dust collection. The opacity was never reduced below approximately 458 during the entire period.

At 0743 hours on August 4, 1992, several indications pointed to a tube leak on the outside of the boiler (inside the combustor). The combustor was tripped at 0821 hours in order to avoid further damage from the suspected leak. Outage inspection revealed a leak in a drain connection weld

Tidd PFBC Demonstration Project DOE Instrument DE-FC21-87 MC24132.000
Technical Progress Report

21 Third Quarter CY 1992 
on the boiler bottom header.

The gas turbine was tripped from the MCS at 1154 hours on August 4, 1992.

5. Start-up TD-SU-92-12-01 - August 8 - 27, 1992

The combustor was released by the Maintenance Department at 1435 hours on August 8,1992 . Gas recirc warming was initiated at 1745 hours.

The gas turbine was rolled at 2337 hours, paralleled at 2356 hours, and the turbine valves were opened at 0001 hours on August 9, 1992.

The bed preheater was lit off at 0558 hours on August 9, 1992. Increased minimum firing set point was again used.

The bed level was increased using bed ash reinjection. The steam turbine was rolled and paralleled at 1254 hours, with a coal fire being initiated at 1349 hours.

Sorbent injection was started at 1616 hours with the east line.

Bed level was increased to approximately 50 inches and maintained to build bed ash inventory.

Tidd PFBC Demonstration Project DOE Instrument DE-FC21-87 MC24132.000
Technical Progress Report

22 Third Quarter CY 1992


The stack opacity was unusually high from the time bed material was staxted into the bed until a bed level of approximately 80 inches was attained. Tegts were conducted on the precipilator TR sats and it was determined that "back corona" existed and was preventing collection of the ash. ("Power off" ra* ping of each field for approximately 45 minuces cured the problem and the stack opacity was mairibained at 108 in energy management mode for the remairiar of the run.)

During the lower hed level conditions, a total of seven dust loeding tests on the precipitator inlet duct were conducted by Environmental sampling Services.

At 0117 hours on August 10, 1992, the \#4 paste pump tripped due to low splitting air flow. Manual reversing cleared the splitting air tube, but the nozzle was still plugged. Several hours later, after many unsuccessful attempts, the nozzles was cleared and the pump was recurned to service at 0349 heurg.

While increasing air flow, the low pressure turbine spead whis quickly brought through the critical speed range of 4550 - 4510 RPM Ly closing the LPC inlet guide vane and increasing the air flow demand.

During the next several days, problems were experienced with \#4, \#5, and \#6 paste pumps pumping inconsistently. The problem was, once again, caused by poor distribution of paste in the tanks.

Tidd PFBC Demonstrition Project DOE Instrument DE-FC21-87 MC24132.000
Technical Progress Repori 23 Third Quarter CY 1992 
At 0310 hours on August 13, the sorbent prep system vibrating screen motor bearings failed. Bed level was lowered to reduce sorbent usage while repairs were made. The motor was repaired and at 1514 hours, sorbent prep was started and bed level was increased.

Problems were experienced very early in the start-up with the coal prep system crusher. Skewing was a problem and the recycle rate could not be operated high enough to obtain a good product ( $f$ ines) and to keep the throughput high enough to support the needed firing rate. On August 14, 1992, the screws were reinstalled above the crusher and both throughput and an acceptable coal paste were achieved.

Prepared sorbent mixing with the coal paste was tested during the week of August 17. A 50\% rate was tested from August 17 through August 19, 1992, and a 1008 rate was tested from August 19 through August 21, 1992.

At 1320 hours on August 21, 1992, the return roller bearing on conveyor \#2 failed. Bed level was reduced to conserve coal. The bearing was replaced and on August 22, 1992, the bed level was again increased for testing of sorbent fines.

The sorbent fines mixed with the coal paste test was conducted August 24 through August 26, 1992.

After completion of the sorbent-in-paste testing and sample collection, the unit was shut down for tube bundle inspection. The combustor was tripped at 0341 hours on August 27, 1992, the unit was cooled and secured in the

Tidd PFBC Demonstration Project

DOE Instrument DE-FC21-87 MC24132.000
Technical Progress Report

24 Third Quarter
CY 1992 
normal manner. The gas turbine tripped at 1028 hours. The combustor continued to be cooled for maintenance outage work.

6. Start-up TD-SU-92-13-01 - September 13 - 15, 1992

The combustor was released by the Maintenance Department at 1053 hours on september 13, 1992. Gas recirc was started at 1536 hours, but warming of the boiler was not started until a 0 pressure balance was accomplished with systems 741 and 758. Vacuum was applied to the secondary ash line prior to starting the gas recirculation.

The gas turbine was rolled at 2251 hours and was paralleled at 2311 hours. The valves were reset and air heating of the combustor began at 2316 hours.

All secondary cyclone dip legs evidenced signs of being plugged, except for Numbers 22 and 24.

Bed level was increased and the steam turbine was rolled and paralleled at 1906 hours. During this time, the \#24 secondary cyclone plugged.

Coal fire was ordered on at 0127 hours on September 15, 1992. The \#3 paste pump failed to start and the function group was ordered off. The pump was run in recirc locally and then was stopped. The function group was ordered on again at 0132 hours. Bed temperatures rose at an extremely fast rate. $\mathrm{O}_{2}$ levels dropped rapidly, the boiler water circuits entered into a large swing, and the boiler circ

Tidd PFBC Demonstration Project

DOE Instrument DE-FC21-87 MC24132.000
Technical Progress Report

25 Third Quarter CY 1992 
flow went low enough to trip the combustor at 0136 hours.

After securing the unit, the paste pumps were reversed. All indications were that the reverse sequence was acceptable.

The bed preheater was lit off at 0208 hours. The steam turbine was rolled and paralleled at 0443 hours.

At 0538 hours, a coal fire was ordered on, but the \#3 coal paste pump again did not start. The function group was ordered off. It was recirculated again locally, then returned to automatic. At 0546 hours, a coal fire was again ordered on, but \#5 paste pump was the only one which did not have an over hydraulic problem. Unsuccessful attempts were made to unplug the nozzles, and the combustor tripped at 1115 hours. The gas turbine tripped at 1257 hours.

The unit was then releaged to the Maintenance Department to clean the paste nozzles and the secondary cyclones.

7. Start-up TD-SU-92-14-01 - September $19-21,1992$

The gas turbine was rolled at 1332 hours on September 20, 1992, and was paralleled at 1349 hours. The valves were reset and air heating of the combustor began at 1400 hours.

The LPC was cleaned with carbo-blast injection during the warming period. 
The bed preheater was lit at 1922 hours. Bed level was increased. The steam turbine was rolled and paralleled at 1906 hours.

At 0121 hours on september 21, 1992, a coal fire was initiated. Bed temperatures rose very fast. Fuel master was cut, but the combustor tripped at 0128 hours on two bed temperature thermocouples greater than $1670^{\circ} \mathrm{F}$.

After paste line reversing, the \#2 and \#3 nozzles were still plugged. The bed was taken back up into the reinjection vessels, and plans were made to remove the gas turbine from service to clean the fuel nozzles from outside of the combustor. At 0543 hours, the gas turbine tripped because of fictive disc temperature differential.

8. Start-up TD-SU-14-02 - September $21-22,1992$

After the cleaning of all six paste nozzles from the outside of the combustor, the gas turbine was rolled at 2107 hours on September 21, 1992, and was paralleled at 1349 hours. The valves were reset at 1400 hours.

The paste nozzles were checked for flow with LP nitrogen. The \#1 nozzle did not show a clean flow of nitrogen. The bed level was lowered to six inches, and a reverse sequence attempted. This also failed to show good flow. It was determined that the isolation valve, HCV-B711, was not seating. The gas turbine was removed fxom service at 0139 hours on september 22, 1992, the valve was disassembled, and the seat repaired. The angle valve used for clean blowing

Tidd PFBC Demonstration Project

DOE Instrument DE-FC21-87 MC24132.000
Technical Progress Report

27 Third Quarter CY 1992 
was also replaced because of leakage and opening problems.

9. Start-up TD-SU-92-14-03 - September $22-24,1992$

Following the repair to the \#1 paste line isolation valve, the gas turbine was rolled at 1001 hours on September 22, 1992. Parallel was at 1018 hours and the valves were opened at 1029 hours.

The bed preheater was lit at 1242 hours. Bed level was increased and the steam turbine rolled and paralleled at 1553 hours.

Coal ignition was accomplished at 1944 hours. Bed temperatures again increased very rapidly. The fuel master set point was lowered to 10.5\%. Air flow was increased to $425 \mathrm{kpph}$, freeboard mixing was initiated, then sorbent injection with the east line was started at 2035 hours.

Bed level was increased to 45 inches and held there to build bed material inventory.

When sorbent injection swapped to the west line, material would not feed out of the bottom of the injection vessel. The system was operated on single-line operation with the east line. Maintenance worked on the west injection vessel outlet. Wet material was found to be the problem. (This line was returned to service at 1436 hours on september 23 , 1992 .) 
Once-through operation was accomplished at 0740 hours on September 23, 1992, with an indicated bed level of 62 inches.

Increased bed level to the 112 inch tap to hold there for the intended limestone injection test.

Estimates are that the limestone sorbent arrived in the bed at 2200 hours.

At approximately 0200 hours on september 24, 1992, the bed conditions became unstable. Evaporator outlet tube temperatures were increasing into alarm, hot and cool spots were observed in the bed, and some sinters were found in the bed ash removal system.

The splitting air flow was increased and bed level decreased in an attempt to eliminate sintering and to improve the bed dynamics. Conditions did not improve and at 0510 hours, the combuator tripped becauge of three bed temperature thermocouples 1 ess than $1200^{\circ} \mathrm{F}$.

All bed material was removed, the gas turbine removed from service at 1014 hours, the combustor was cooled and then released to the Maintenance Department for outage work.

10. Start-up TD-SU-92-15-01 - September 28 - October 1, 1992

The combustor was released by Maintenance at 2000 hours on September $28,1992$.

Tidd PFBC Demonstration Project

DOE Instrument DE-FC21-87 MC24132.000
Technical Progress Report 29 Third Quarter
CY 1992 
The combustor warming was accomplished by starting the air circulation, establishing 0 pressure in the freeboard with $741 / 758$ system, then warming the boiler circuits.

The gas turbine was rolled at 0706 hours on september 29, 1992. Parallel was at 0726 hours, and the valves were opened at 0733 hours. Unusual vibration and noise were detected on the LPC housing during the air heating period.

The bed preheater was lit at 1346 hours. The test $\mathrm{O}_{2}$ analyzer lines were found to have leaks just outside of the combustor. These lines were plugged with high temperature RTV to prevent leaks.

Water mist nozzles were used on the inlet to the precipitator in an attempt to increase the collection of the ash. This appeared to help until after coal fire when the bed level was increased.

Bed level was increased for the steam turbine roll. The steam turbine stop valve trip solenoid coil failed and was replaced. At 2031 hours, the steam turbine was rolled and was paralleled at 2132 hours.

Coal fire was initiated at 2222 hours. The \#3 paste pump was pumping much lower flow than the others. The bias was increased to 1.5. This helped, but tuning in logic was required to bring the flow up to what was needed. Bed temperatures increased slowly, and the fuel master set point was increased to 12.58 . 
The vibration on \#1 and \#2 bearings of the gas turbine increased until air flow was increased above $375 \mathrm{kpph}$. Air flow increase was stopped at $400 \mathrm{kpph}$, splitting air flow bias set to 1.25 , freeboard mixing was initiated, then sorbent injection with the east line was started at 2.327 hours. Splitting air flow bias was increased $.05 \%$ at a time to a bias of 1.55 at a bed level of 45 inches (splitting air flow at this time was $3875 \mathrm{ppm})$.

Bed level was maintained at 45 inches to build bed inventory .

Once-through operation was accomplished at 0557 hours on September 30, 1992.

At approximately 0800 hours, water was found in the economizer outlet duct drain. The precipitator inlet duct water injection was shut down to determine if this water was coming from that operation. (Outage inspection proved that this was true.)

At 1143 hours, air flow was decreased because of high vibration on the \#1 bearing of the gas turbine.

Splitting air flow bias was increased to 1.58 and a flow of $3950 \mathrm{kpph}$.

Bed level was increased to the 112 inch tap to hold there for the intended limestone injection test.

Tidd PFBC Demonstration Project DOE Instrument DE-FC21-87 MC24132.000
Technical Progress Report 31 Third Quarter CY 1992 
Some sinters were found in the bed ash removal system and at approximately 2100 hours, the sinter production seemed to be increasing, and evaporator tube temperatures and bed temperatures became erratic. Water was added to the coal paste tank in an effort to cause the paste to split better in the bed. splitting air flow was increased to try to improve conditions. Nothing appeared to have any significant effect.

The combugtor was manually tripped at 0101 hours on October 1, 1992, because of the very poor bed dynamics.

All bed material was removed, the gas turbine removed from service at 0446 hours, and the combustor was cooled and then released to the Maintenance Department for outage work.

\section{B. Maintenance}

1. Outage TD-OT-92-09 - July $11-26,1992$

Realigned south circulating water motor.

Made weld repairs on sorbent preparation system fan.

Built up rotor on sorbent preparation crusher using hard surface welding rod.

Removed telemetering device from the outside of the gas turbine IPT shaft. 
Installed one additional economizer sootblower and revised controls for all sootblowers.

Replaced the pickup pot on \#24 cyclone with the one from \#21. They are now all the same.

Repaired tube leaks on \#4 feedwater heater.

2. Outage TD-OT-92-10 - July 27 - August 1, 1992

Removed large sinters from both bed ash reinjection vessels.

Removed hard deposits from the $O_{2}$ analyzer lines.

Replaced two tile sections at sparge duct expansion joints.

Installed $12 \mathrm{~mm}$ orifices in the primary cyclone fluidizing lines.

Removed the diverter plate from the center of the coal paste tank.

3. Outage TD-OT-92-11 - August $4-8,1992$

Repaired leak on boiler bottom header drain line weld.

Revised paste tank agitators with extension on one set of blades in each tank.

Reinstalled screw feeder above coal preparation system crusher. 
Installed larger motor on economizer sootblower seal air fan.

Installed baffle plate on sorbent preparation system vibrating feeder.

4. Outage TD-OT-92-12 - August 27 - September 13, 1992

Reinstalled original piston in south cylinder of \#3 coal paste pump.

Added extension to sorbent preparation system velocity separator.

Installed new carburized sorbent injection lines.

Installed new orifice in primary cyclone ash $\mathrm{V}-102$.

Repaired six cracks in sparge ducts.

5. Outage TD-OT-92-13 - September $15-19,1992$

Inspection of secondary cyclone ash system revealed moist ash and peelings from eyclones. Sandblasted/cleaned cyclones.

Cleaned hard deposits from the north collection header on the secondary internal ash cooler.

Tidd PFBC Demor.stration Project DOE Instrument DE-FC21-87 MC24132.000
Technical Progress Report 34 Third Quarter CY 1992 
Loaded sand for start-up into the bed ash reinjection vessels.

6. Outage TD-OT-92-14 - September $24-28,1992$

Cleaned sinters from bed area.

Cleaned hard deposits from $\mathrm{O}_{2}$ analyzer lines.

Loaded sand for start-up into the bed ash reinjection vessels.

C. Performance

1. Made logic changes in low $\mathrm{O}_{2}$ combustor trip circuits.

2. Refined bed temperature control logic. 


\section{MANPOWER REPORT}

As of September 30, 1992, AEPSC actual work-hours for Phase III accounted for 21.68 of the total budget of 135,098 . Figure 1 represents the budget versus actual work-hours for this phase.

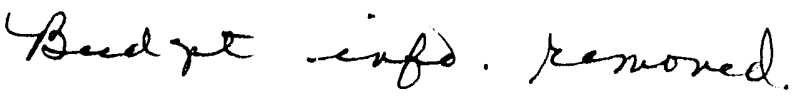

Tidd PFBC Demonstration Project Third Quarter CY 1992 

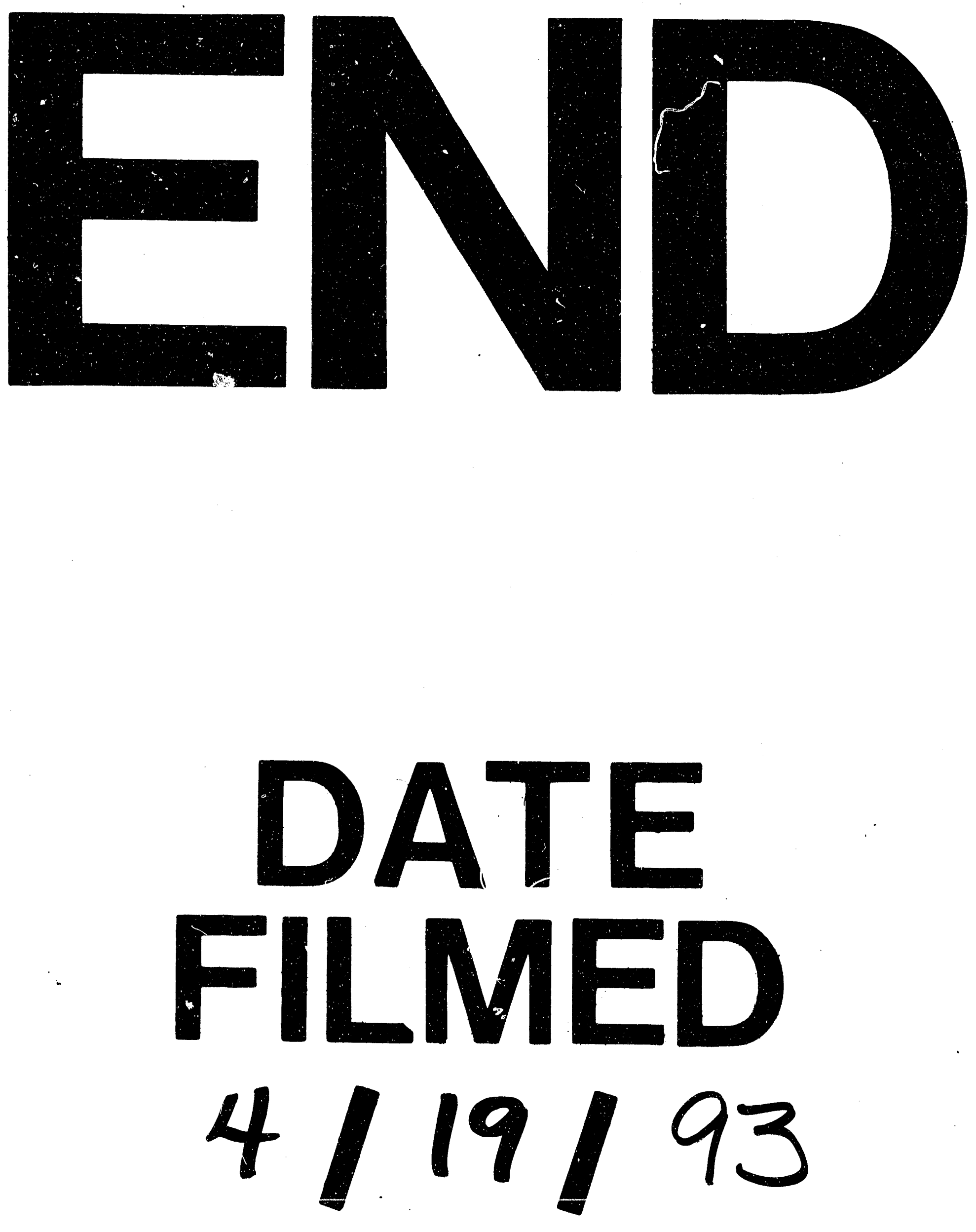
